\title{
AN APPRAISAL OF THE OPERATIONAL PROBLEMS HINDERING THE PROTECTION OF PERFORMER'S RIGHTS AS COPYRIGHT IN NIGERIA
}

\author{
Nkem Itanyi ${ }^{*} \&$ Madunatu Chikaodili Nwamaka ${ }^{* *}$
}

\begin{abstract}
Intellectual creation occupies a prominent place within the economic, social and cultural development of each nation; the wellbeing of a country is also appreciated by its capacity to create, introduce, manage and exploit intellectual assets beyond its natural resources, its labour or capital. Protection of intellectual property rights is of particular importance because the essence, goal and purpose are to protect the product of human intelligence and at the same time to guarantee for the benefit of consumers the use of such produce. Copyright and neighbouring rights are one of the main branches of Intellectual Property rights. Copyright is a significant specie of intellectual property which includes literary works, musical works, artistic works, cinematograph films, sound recordings and broadcasts. Neighbouring rights refer to the rights of a live performer also known as performer's rights. Both copyright and neighbouring rights are protected under the Copyright Act, even though the Act makes independent provisions for each. This paper discusses the statutory framework dealing specifically with the protection of neighbouring rights and examines how neighbouring rights have been protected in international copyright laws; The Rome Convention, Trade Related Intellectual Property Rights (TRIPS), both of which Nigeria is a signatory to, and the Beijing Treaty which for the first time in international copyright extends protection to live performance. The operational problems encountered in the course of enforcing neighbouring rights are highlighted and suggestions proffered on how to alleviate same.
\end{abstract}

INTRODUCTION

I. HISTORICAL EVOLUTION OF COPYRIGHT AND NEIGHBOURING RIGHTS ...610 II. NATURE OF RIGHTS UNDER COPYRIGHT AND NEIGHBOURING RIGHTS ... 611 A. International Instrument for the Protection of Performer's Rights 613

B. Domestic Legal Framework on Copyright and Neighbouring Rights 618

III. OPERATIONAL PROBLEMS LIMITING THE ENFORCEMENT OF NEIGHBOURING RIGHTS

\footnotetext{
${ }^{*}$ L. L. B. (Ife) L. L. M. (Lond), BL. Lecturer in the Department of Commercial and Corporate Law, Faculty of Law, University of Nigeria. Research fields: Intellectual Property Law, Commercial Law and Company Law.

${ }^{* *}$ L. L. B. (Nig.) BL. Associate, McCarthy, Mbadugha \& Co. Lagos. Research fields: Intellectual Property Law, Corporate Commercial and Alternative Dispute Resoulutions (ADR).
} 
IV. ENFORCEMENT AND PROTECTION OF PERFORMER'S RIGHTS IN NIGERIA: THE POSITION OF THE COURT AND THE NigERIAN COPYRIGHT COMMISSION (NCC) IN THE ENFORCEMENT OF PERFORMER'S RIGHTS .... 626

V. TACKLING THE Challenges Facing PeRFormer's Right 629

CONCLUSION 631

\section{INTRODUCTION}

It is a truism that copyright is a type of intellectual property which is founded on a person's creative skill and labour. Copyright can be described as the exclusive right of the owner of copyright to control the exploitation of his work and to grant authorisation to others in this regard, subject to certain limitations and exceptions. Copyright seeks to protect all original literary, artistic, musical works, cinematograph films, just to mention a few.

The expression "neighbouring rights" has no precise meaning or definition. It is the English translation of the French words "Droits voisins", and it is considered "near" to the musical work copyright. These kinds of rights are normally called "related rights" or "secondary rights" or "performer's rights". It is the right of performers to give or withhold consent to the exploitation of their performances; the right of producers of sound recordings and films to give or withhold consent to the reproduction of their recordings or films; the right of broadcasting organisations to authorise or prohibit the use of their programmes. Neighbouring rights on its part, seek to accord to those who contribute to the diffusion of the original literary and artistic creation some prerogative rights in their work particularly. Neighbouring rights are also known as performer's rights. There is an inherent value in live performance, as it is clear that members of the public are more than willing to congregate at a theatre or music venue to pay for a live performance. However with the advancement of technology, performance may now be enjoyed outside of that environment as it becomes cheap and easy with the aid of technologies like audio and video recorders and computers to make a mechanical reproduction of a performer's work ${ }^{1}$. This frequently is done without the consent of the performer. Many Nigerian youths continually perform in reality shows and their performances are broadcast and rebroadcast by television stations, often without their consent.

This paper is divided into five parts. The first Part talks about the introduction and the historical evolution of the concept of copyright and

\footnotetext{
${ }^{1}$ Sanjay Pandey, Neighbouring Rights Protection in India, 9(4) Journal of InTELleCtual ProPerty RIGHTS 356-370.
} 
neighbouring rights as a precursor to Section I wherein there is an examination of the institutional framework on copyright and neighbouring rights; Section II, the nature of rights under copyright and neighbouring rights as well as the international instrument for the protection of performer's rights. Section III highlights the operational problems encountered in the enforcement of neighbouring rights. Sections IV and V focus on enforcement and protection of performer's rights in Nigeria. Recommendations on how to tackle the challenges facing performer's rights and the concluding remarks are made in the last Part.

\section{HistoricAl EVOLUTION OF COPYRIGHT AND NEIGHBOURING RIGHTS}

The historical development of copyright in Nigeria can be seen from early times in some form of property right in different kinds of intellectual products or works of mind, although the exact nature of the right granted differed from one culture to another. Societies where writing had developed to some appreciable level recognised some form of proprietary right in the physical material embodying the writings, even if such rights were not exactly the same as the modern concept of copyright. Some forms of quasicopyright practices have been found in Hausa-Fulani ${ }^{2}$ and Yoruba $^{3}$ literature where the poems have been reduced to writing with the acknowledgement of their original authors.

The history of the protection of copyright in Nigeria can be traced to the United Kingdom Copyright Act of 1911. The Act ${ }^{4}$ was made applicable in Nigeria by an order-in-council. Being prompted by the need for a domestic legislation, the Federal Military Government in 1970 promulgated the Copyright Decree No. 61 of 1970. Section 18 in the Decree repealed the Imperial Copyright Act of 1911. There was a lacuna in the 1970 Act which led to the promulgation of the Copyright Decree No. 47 of 1988. The Act was further amended in 1999 and 2004. The current text of the Copyright Act (as amended) is contained in Cap. C28 Laws of the Federation of Nigeria 2004.

On the other hand neighbouring rights have existed for as long as live performances were accessible to spectators within the performer's own immediate vicinity. Consequently, his interest was easily protected by the law of contract through which the performer could collect payment for his

\footnotetext{
${ }^{2}$ R. Finnegan, Oral Literature In Africa 20 (Nairobi: Oxford University Press 1970).

${ }^{3}$ J. Timothy, Asobele "Oral Poetry in Nigeria" (a Millennium of Poetry in Music), 143 NigERIA MAGAZINE 15 (1982).

${ }^{4}$ Ibid.
} 
performance. Therefore, there was little need for further protection in the nature of exclusive right. However, in the late nineteenth century and the early twentieth century, technology was developed that enabled performances to be recorded, and subsequently enabled both live and recorded performances to be broadcast and communicated to the public locally, regionally, nationally and eventually internationally. The development of laws giving performers rights in their performances stemmed from complaints made by performers, primarily in European countries, that they needed specific legal protection against the use of their performances in ways that deprived them of employment and they had not authorised. The first complaint was a claim for protection against technological unemployment, the replacement of musicians by recorded music. The second complaint initially concerned the practice of "bootlegging.",

With respect to statutory provision, the 1970 Copyright Act $^{6}$ made no provision for neighbouring rights, partly because Nigeria had then not ratified the Rome Convention and technologies were only just beginning to become popular in the country. As technology developed, performer's demands were for rights to control the uses of their performances so that they could secure greater financial returns. Thus, with the promulgation of the present Copyright Act in $1988,{ }^{7}$ the regime of protection of neighbouring rights was introduced.

\section{NATURE OF RightS UNDER COPYRIGHT AND NEIGHBOURING RighTS}

Copyright includes literary works, musical works, artistic works, cinematograph films, sound recordings, broadcasts, live performances and expressions of folklore. Literary works include novels ${ }^{8}$, stories, choreographic works ${ }^{9}$, computer programmes, lectures ${ }^{10}$ etc. Musical works ${ }^{11}$ also include works composed for accompaniment. Artistic works ${ }^{12}$

\footnotetext{
${ }^{5}$ The making unauthorised recordings of live performances either directly at a concert or indirectly from a live broadcast.

${ }^{6}$ Copyright Decree (No. 61) 1970.

${ }^{7}$ Nigeria became member of this convention on October 29, 1993.

${ }^{8}$ Glyn v. Weston Feature Films Co. [1910] 1 CH 261; Fernald v. Jay Lewis Productions Ltd [1975] F. S. R. 499.

${ }^{9}$ Defined in section 51 Nigerian Copyright Act as a composition of movement for dancing or any other patterned succession of gestures mostly created to accompany music.

${ }^{10}$ Nicol v. Pitman [1884] L.R. 26 CH. D. 374.

${ }^{11}$ Wood v. Booser [1896] L.R. 3 QB. 203.

${ }^{12}$ Kendrick \& Co v Lawrence \& Co [1890] 25 Q. B. D. 99.
} 
include paintings, drawings, wood maps, etc. Cinematograph films ${ }^{13}$ include fixation of sequence of visual image that can be seen and associated sound tracks that can be heard. Sound recording ${ }^{14}$ is a fixation of sequence of sound capable of being perceived but does not include sound tracks associated with cinematograph films; broadcasts. In the case of broadcasts, the subject matter of protection is not the artistic content but the final package as put together by the entity behind the production of the work. ${ }^{15}$

These works will be eligible for copyright if sufficient efforts have been expended to give them an original character (originality) and if the works have been fixed in a medium of expression (fixation) now known or later to be developed. Copyright in musical and literary works for example, guarantees the exclusive right of the owner to reproduce, publish, perform, adapt, distribute, sell and broadcast. An artistic work ${ }^{16}$ will also guarantee the owner of the exclusive right of control of the reproduction, publication and adaptation of the work. In the case of a cinematograph film, ${ }^{17}$ the copyright owner can exclusively control the direct or indirect reproduction and distribution. The copyright owner of a broadcast ${ }^{18}$ has the exclusive control of the recording and communication of the work.

Creators of original works also have moral rights in their works. The aim of moral rights is to strike a balance between the interests of the commercial exploitation of a protected work and the interests of the creator of the protected work. Moral rights include the right of an author to claim ownership in his or her work (the paternity right), and the right of the author to oppose changes to the work that could have a negative effect on the author's reputation (the integrity right).

A performer's rights are a type of intellectual property rights that are sometimes called "neighbouring rights" or "related rights" i.e., they neighbor on or are related to copyright. Hence, it is not uncommon for those rights to be found in a country's copyright legislation. Neighbouring rights on their own were created for three categories of people who may not be technically or exclusively authors ${ }^{19}$ viz: performers, producers of phonogram, broadcasting organisations. These rights relate to the sound

\footnotetext{
${ }^{13}$ American Motion Pictures Export Co. (Nig.) Ltd v. Minnesota Nigeria Limited [1981] F. H. C. R. 394.

${ }^{14}$ Island Records Ltd \& 8 Ors. v. Pandum Technical Sales \& Service Ltd [1993] F. H. C. L. 69.

${ }^{15}$ J. O. AsEin, Nigerian COPYRIGHT LAW AND PRACTICE 24 (Abuja, Books \& Gavel 2012).

${ }^{16}$ Section 6(1) (b), Nigerian Copyright Act (NCA).

${ }^{17}$ Section 6(1) (c), ibid.

${ }^{18}$ Section 8, ibid.

${ }^{19}$ This is because, they could be authors but their works (live performance) are not protected as such under copyright in the strict sense of it.
} 
recording of a musical work (the particular, singular and unique performance of a musical work, when performed by an artist and recorded on a media).

Nonetheless, this doesn't mean that these rights are lower in amount or "quality". Simply they came after the author's rights were already in place and are treated in a similar manner.

However, the $\mathrm{Act}^{20}$ gives the performer exclusive right to control with respect to his performance, the performing, recording, live broadcasting, reproducing in any material form, and adaptation of the performance.

\section{A. International Instrument for the Protection of Performer's Rights}

As earlier stated, the idea of protecting performers took shape in the period following the First World War, owing to the development of new technical media that facilitate the use of the performance of artist through, audio-visual, phonograms or broadcasting. Because of this, special instruments emanated to accord protection for performers from unauthorised use of their work. They are: the Rome Convention of 1961, the Agreement on Trade Related Aspect of Intellectual Property Rights (TRIPS) of 1995 and the Beijing Treaty of 2016 where for the first time in international copyright law protection was extended to live performances.

\section{The Rome Convention}

This convention is known as the International Convention for the Protection of Performers, Producers of Phonograms and Broadcasting Organisation. It came into existence because of demand for greater protection of their work from performer's organisation and musical union. The convention covers in a single instrument, the protection of performers, producers of phonograms and broadcasting organisation. The protection provided under this convention differs according to whether it is to be granted to artists or to producers of phonograms and broadcasting organisation. It is pertinent to state here that in discussing the provisions of this convention, focus would be placed on the protection granted to performers in their live performances. The convention defines "performers" to mean actors, singers, musicians, dancers and other persons who act, sing, deliver, declaim, play in, or otherwise perform literary or artistic work. ${ }^{21}$

\footnotetext{
${ }^{20}$ Section 23 NCA.

${ }^{21}$ Article 11 of the International Convention for the Protection of Performers, Producers of Phonograms and Broadcasting Organisations (Rome Convention).
} 
Here, performers are protected against certain acts to which they have not consented, such as the broadcasting and communication to the public of a live performance, the fixation of their live performances, the reproduction of the fixation if the original fixation was made without the performer's consent or if the reproduction was made for the purpose different from those for which consent was given. ${ }^{22}$ The Rome Convention allows for limitations and exceptions to the above-mentioned rights on national laws as regards private use, use for short excerpts in connection with reporting current events, ephemeral fixation by a broadcasting organisation by means of its own facilities and for its own broadcast, use solely for the purpose of leading or scientific research and in any other cases where national law provides exceptions to copyright in literary and artistic works. ${ }^{23}$ Suffice it to say here that irrespective of these exceptions and limitations, any contracting state may, in its domestic laws and regulations, provide for this kind of exception or limitations with regards to the protection of performer's right. ${ }^{24}$

Furthermore, once a performer has consented to the incorporation of a performance in a visual or audio visual fixation the provision on performer's right would have no further application. ${ }^{25}$ Again, the provision of this convention notwithstanding shall not prejudice any protection otherwise secured to the performers. ${ }^{26}$ The protection granted by this convention is for a period of twenty years computed from the end of the year in which their

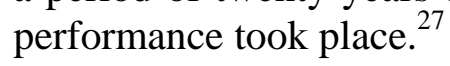

2. The Agreement on Trade Related Aspects of Intellectual Property Rights (TRIPS)

Intellectual property issues gained prominence at the Uruguay Round of the multilateral Trade Negotiations on the General Agreement on Tariffs and Trade (GATT) with intellectual property being viewed as a crucial component in the multilateral trading system. The result of this was The Agreement on Trade Related Aspects of Intellectual Property Rights (TRIPS) concluded as part of the World Trade Organization (WTO) Agreement. ${ }^{28}$ The TRIPS Agreement, which came into effect in January 1995, is to date

\footnotetext{
${ }^{22}$ Article 7, ibid.

${ }^{23}$ Article 15 , ibid.

${ }^{24}$ Article 15(2), ibid.

${ }^{25}$ Article 19, ibid. This is because the whole essence is protection against unauthorised use of the performer's work.

${ }^{26}$ Article 21, ibid. For instance, a performer who is a member of a collecting society would not be robed off the protection granted by this convention.

${ }^{27}$ Article 14, ibid.

${ }^{28}$ J. O. Asien, Op. Cit., at 388.
} 
the most comprehensive multilateral agreement on intellectual property. However, many developing countries hold that TRIPS agreement is unbalanced in that it favours developed countries and transnational corporations, and at the same time is unhelpful or even harmful to their own interest. In addition, concerns have been raised about the move to ensure that developing countries accept higher standards of intellectual property protection than what the WTO requires. This is so even before they have determined how best to implement the TRIPS agreement in ways that support economic development and poverty alleviation. Non-governmental organisations have criticised TRIPS on the grounds that it imposes various costs on developing countries without producing sufficient long-term gain in areas like trade and investment. ${ }^{29}$

Notwithstanding the above, the rights covered by TRIPS include copyright, related rights (performer's right), trademarks, geographical indications, industrial designs, and patents, layout designs of integrated circuits, protection of undisclosed information (trade secrets) and control of anti-competitive practices in contractual licences. The TRIPS agreement has three main features, namely, standards, which deals with the minimum standard of protection to be provided by each member. ${ }^{30}$ Each of the main elements of the protection is defined, namely, the subject matter to be protected, the right to be conferred and permissible exceptions to those rights and the minimum duration of protection. The second feature of the agreement deals with domestic procedures and remedies for the enforcement of intellectual property rights. Thirdly, the agreement makes dispute resolution in respect of the TRIPS obligation subject to WTO's dispute settlement procedures.

Under the TRIPS Agreement the performers shall have the possibility of preventing the unauthorised fixation of their performances in a phonogram (for example, the recording of a live musical performance); the fixation of their unfixed performance and the reproduction of such fixation, the broadcasting by wireless means and the communication to the public of their live performance. ${ }^{31}$ The term of protection available under this agreement to performers and producers of phonograms is fifty years from the end of the calendar year in which the fixation was made or the performance took place. $^{32}$

\footnotetext{
${ }^{29}$ Overview of the TRIPS Agreement, www.wto.org (Retrieved on October 7, 2016).

${ }^{30}$ Article 1 of the TRIPS Agreement of 1995.

${ }^{31}$ Article 14(1), ibid.

${ }^{32}$ Article 14(5), ibid.
} 


\section{The Beijing Treaty}

The Beijing Treaty on audiovisual performances was adopted by the diplomatic conference on the protection of audiovisual performances which took place in Beijing from June 20 to 26, 2012. The treaty deals with intellectual property rights of performers in audiovisual performances. The Beijing Treaty modernises and updates for the digital era the protection for singers, musicians, dancers and actors in audiovisual performances contained in the Rome Convention of $1961 .{ }^{33}$ The Beijing Treaty grants performers economic rights in fixed and unfixed performances. ${ }^{34}$ It grants performers four kinds of economic rights for their performances fixed in audio-visual fixations, such as motion pictures: (i) the right of reproduction $^{35}$, (ii) the right of distribution ${ }^{36}$, (iii) the right of rental ${ }^{37}$, and (iv) the right of making same available ${ }^{38}$. As to unfixed (live) performances, the Treaty grants performers three kinds of economic rights: (i) the right of broadcasting $^{39}$, (ii) the right of communication to the public ${ }^{40}$, (iii) the right of fixation ${ }^{41}$. In addition to these economic rights granted to performers, the treaty also grants moral rights to performers, thus, the performer shall have the right to be identified as the performer of his performances, except where omission is dictated by the manner of the use of the performance; and to object to any distortion, mutilation or other modification of his performances that would be prejudicial to his reputation, taking due account of the nature of audiovisual fixation. ${ }^{42}$

The Treaty provides that performers shall enjoy the right to authorise the broadcasting and communication to the public of their performances fixed in audiovisual fixations. However, contracting parties may notify that instead of the right of authorisation, they will establish a right to equitable remuneration for the direct or indirect use of performances fixed in audiovisual fixations for broadcasting or communication to the public. Any Contracting Party may restrict or, provided that it makes a reservation to the Treaty, deny this right. In the case and to the extent of a reservation by a Contracting Party, the other Contracting Parties are permitted to deny, vis-à-

\footnotetext{
${ }^{33}$ Rome Convention was the first convention that aims at protection of performer's right.

${ }^{34}$ Article 6 of the Beijing Convention 2012.

${ }^{35}$ Article 7, ibid.

${ }^{36}$ Article 8, ibid.

${ }^{37}$ Article 9, ibid.

${ }^{38}$ Article 10, ibid.

${ }^{39}$ Article 11, ibid.

${ }^{40}$ Ibid.

${ }^{41}$ Article 6(ii).

${ }^{42}$ Article 5(1).
} 
vis the reserving Contracting Party, national treatment "reciprocity". ${ }^{43}$ The enjoyment and exercise of the rights provided for in the Treaty cannot be subject to any formality. ${ }^{44}$

As to the transfer of rights, the Treaty provides that Contracting Parties may stipulate in their national laws that once a performer has consented to the audiovisual fixation of a performance, the exclusive rights mentioned above are transferred to the producer of the audio-visual fixation (unless a contract between the performer and producer states otherwise). Independent of such a transfer of rights, national laws or individual, collective or other agreements may provide the performer with the right to receive royalties or equitable remuneration for any use of the performance, as provided for under the Treaty. ${ }^{45}$

As to limitations and exception, the Beijing Treaty provides that contracting states may, in their national legislation, provide for the same kinds of limitations or exceptions with regard to the protection of performers as they provide for, in their national legislation, in connection with the protection of copyright in literary and artistic works. ${ }^{46}$

The term of protection to be granted to performers under this Treaty shall last, at least, until the end of a period of 50 years computed from the end of the year in which the performance was fixed. And in the case of moral right the rights granted to a performer shall, after his death, be maintained, at least until the expiration of the economic rights. ${ }^{47}$

The adoption of the Beijing Treaty on audiovisual performances strengthens the precarious position of performers in the audiovisual industry by providing a clear legal basis for the international use of audiovisual productions, both in traditional media and in digital network. Such an instrument it was said would also contribute to safeguarding the right of performers against unauthorised use of their performance in audiovisual media such as television, film and video. In an era of the increasing prevalence of audiovisual productions as well as of audiovisual images in music, digital market consumption has extended beyond open TV broadcasts to pay-TV channels, DVDs and most recently the internet, including the mobile environment. Protection of audiovisual performances will extend to all those expanding audiovisual markets. The Beijing Treaty will strengthen where there is necessary help to consolidate local

\footnotetext{
${ }^{43}$ Article 11(2) \& (3)

${ }^{44}$ Article 17.

${ }^{45}$ Article 12.

${ }^{46}$ Article 13(1).

${ }^{47}$ Article 5(2).
} 
audiovisual industries as they join an international system of protection.

Again, by providing incentives and compensation in regard to the international use of their performances, the Beijing Treaty will strengthen the standing of performers in the audiovisual industry. Performers are both artists and cultural workers. The Beijing Treaty will contribute to raising the professional status of actors and other performers and improving their working conditions. Moreover, the development of performers' rights could lead to the introduction or consolidation of performers' organisations, as well as those of producers, which are their natural counterparts in the exercise of rights for the exploitation of films and other audiovisual content. The development of these representative organisations will facilitate an environment more conducive to social dialogue between artists and producers, which will have the overall effect of strengthening the cinematographic and audiovisual sectors.

In respect of protection of folklores Beijing Treaty came in handy because, apart from being an art form on its own, film is an excellent vehicle for other expressions of creativity and cultural identity. Audiovisual performances can bring the literary works and music of a given culture close to the hearts and minds of the audience in an extremely effective way. This dimension of audiovisual performances as a carrier and multiplier of other creative expressions not only has a tremendous economic significance but is also extremely relevant to furthering cultural diversity. In this same context the Beijing Treaty contributes to the protection of traditional cultural expressions and national folklore, which has been the subject of examination in various World Intellectual Property Organization (WIPO) fora, including the WIPO Intergovernmental Committee on Intellectual Property and Genetic Resources, Traditional Knowledge and Folklore (IGC). As clearly stated in the Beijing Treaty, performers include those actors and singers who interpret an expression of folklore. ${ }^{48}$

\section{B. Domestic Legal Framework on Copyright and Neighbouring Rights}

The first ever copyright law in Nigeria was made applicable to the country by order-in-council. ${ }^{49}$ However, the first domestic law on copyright in Nigeria was passed in 1970. The Act was repealed and replaced by a more futuristic and comprehensive Copyright Act in 1988. It was in 1988 that the regime of protection of neighbouring rights in the live performance

\footnotetext{
${ }^{48}$ Main Provisions and Benefits of Beijing Treaty on Audio-Visual Performances 2012. World intellectual property Organisation (Retrieved on October 8, 2016).

${ }^{49}$ No. 912 of $24^{\text {th }}$ June, 1912.
} 
was introduced for the first time. Again the 1988 Act has been amended in 1992 and 1999 and is now embodied in the 2010 edition of the Laws of the Federation of Nigeria. Works protected under the Act include, literary, artistic and musical works, cinematograph films, sound recordings and broadcasts. ${ }^{50}$ The Act also protects live performances and expressions of folklore known as neighbouring rights. ${ }^{51}$ Performers are given exclusive rights in the $\mathrm{Act}^{52}$ to control, in relation to their live performances, the recording, broadcasting live performance, reproduction in any form and adaptation of the performance. This right conferred on the performers by the Act shall subsist in relation to the performance until the end of the period of fifty years in which the performance first took place. ${ }^{53}$ An infringement of these rights granted shall be actionable by the person entitled to the right as a breach of statutory duty and the performer and the performer shall be entitled to damages, injunction, account for profit or conversion. ${ }^{54}$ The word "by the person entitled to the right" can be understood to mean the holder of the right either as the performer or as an assignee or transferee of the right. Thus, as in the case with copyright, the particular right owned by a person would determine what he is permitted to do or control under the Act. For instance, a person having only a recording right may not authorise the adaptation of the performance nor will he be justified in authorising another to record beyond the extent of his own right. The rights granted are independent of any copyright in the underlying work. So, an unauthorised recording of a live performance would be an infringement of performers' right in the live performance, but if the underlying work is a protected musical work, then an unauthorised recording would also constitute an unauthorised reproduction and infringement of the copyright in the musical work. ${ }^{55}$ In an action for infringement under the Act, the appropriate plaintiff would be the performer. Where an action is brought by any other person who has a right in the performance, he would be required to join the performer. ${ }^{56}$ The section ${ }^{57}$ gives a person having the performer's right or recording right in relation to the performance the right to an order of the court that the recording be forfeited and delivered up to him in the situation where a person has in his possession, custody or control, in the course of

\footnotetext{
${ }^{50}$ Section 1 NCA.

${ }^{51}$ Sections 26-33 NCA.

${ }^{52}$ Section 26 NCA.

${ }^{53}$ Section 27 NCA.

${ }^{54}$ Section 29(1) NCA.

${ }_{55}^{55}$ J. O. Asien, Op. Cit., at 341.

${ }^{56}$ R. C. A. Corp v. Polland (1982) 3 All E. R. 771.

${ }^{57}$ Section 29(2).
} 
trade or business or otherwise than for private or domestic use, an unauthorised recording of a performance.

A performer's right is infringed by a person who without the performer's consent or authorisation in writing makes a recording of the whole or a substantial part of a live performance without the requisite consent or authorisation of the performer. ${ }^{58}$ In the case of the recording of a phonogram creates right for two different groups (1) the performer has the right concerning the reproduction of her performance and (2) the producer of the phonogram has right relating to the reproduction of the phonogram. These rights exist independently of each other; the producer's right is original, not derivative.$^{59}$ The producer is not holden to acquire a license from the performer in order to exercise his right in the phonogram against third parties. An example, if a live performance is fixed without the performer's consent by a producer of phonogram ad a third party reproduces copies of this phonogram, the producer himself is liable for infringement claims by the performer for having fixed a performance without the performer's consent. On the other hand, the performer cannot herself reproduce the phonogram of her fixed performance without the producer's consent. The performer does not have an original right in the pangram and the producer does not have any original right in the performance, consent must be obtained at every stage. However, there is a proviso to the effect that where the consent sought is to make a recording of the work for research, private or domestic use, and such consent shall not be unnecessarily refused. It is pertinent to state here that there is no definition in the Act as to what constitute unreasonable refusal. Hence, one would ask whether the omission implied that consent would be presumed or that the other party could then go ahead and make the recording. ${ }^{60}$

Also there is no provision in the Act for the assignment or transfer of performer's right by a performer. This restriction confirms that those rights are personal to the performer. This however places the performer in a "better" position to bargain for increased remunerate and other benefits from a producer or an employer because he or she has the benefit of nontransferable performer's rights as performers are not usually in a position to resist a producer's demand the fact that performers' right cannot be assigned puts the performer and his heirs at further disadvantages. The nontransferable nature may be an obstacle to the making of performances, given that producers will want to be reassured that they control all the intellectual

\footnotetext{
${ }^{58}$ Section 28 NCA.

${ }^{59}$ Rome Convention Art 10.

${ }^{60}$ J. O. Asien, Op. Cit., at 343.
} 
property rights associated with a production. This problem highlights the importance of the consent that a performer gives to the exploitation of a performance. A wide consent effectively negates the application of performers' rights, at least as far as the person to whom the consent has been given and compensates for the absence of an assignment provisions.

Again, the $\mathrm{Act}^{61}$ provides that an unauthorised public performance of a live performance constitutes an infringement. Such a performance would include radio and television broadcast, cable transmission and satellite retransmission. It also includes other forms of communication through the use of machines, speakers, etc. It is equally an infringement of the performer's right to show or play the performance in public for commercial purposes. The Act in sections $28(\mathrm{f})$ and $(\mathrm{g})$ provides that it is an infringement to import an infringing recording of a performer's work into the country otherwise than for private or domestic use without the consent of the performer. It is equally an infringement to deal on infringing recording of a performer's work.

In addition to the civil remedies for infringement of performer's right, the $\mathrm{Act}^{62}$ creates separate criminal liability. Thus, such a person who does any of the infringing acts shall, unless he proves to the satisfaction of the court that he did not know that his conduct was an infringement of the performer's right, be liable to conviction. The court before which the offence under this section is tried has the discretion to order that the recording or any other part thereof be delivered to the performer. ${ }^{63}$

\section{OPERATIONAL PROBLEMS LIMITING THE ENFORCEMENT OF NEIGHBOURING RIGHTS}

It cannot be doubted that the contribution of performers is an important part of the value of many cultural products. Television programs, films and sound recordings, all require the skill and efforts of performers, and in many cases it is their contribution which provides much of the products' attraction. ${ }^{64}$ We buy a particular recording because we happen to prefer a particular performer. It is therefore not hard to perceive injustice in a system where composers, lyricists and record producers have continuing rights to control and receive payment for commercial uses of such products ${ }^{65}$ but

\footnotetext{
${ }^{61}$ Section $28 \odot$ and (d) NCA.

${ }^{62}$ Section 30(1) NCA.

${ }^{63}$ Section 30(9) NCA.

${ }^{64}$ KimberleE Weatherall, On the InSANEly COMPLiCATEd NEW Regime FOR PERFORMERS' Rights In Australia, AND How AuSTRALIAN PERFORMERs GOT GYPPED 3.

${ }^{65}$ All these parties are copyright owners and hence have continuing rights subject to contract.
} 
performers do not. The first operational problem is that whereas the author's copyright enjoys prominence in both national and international law immediately the work is created; the neighbouring rights of performers are subsequently and may be subsumed in the copyright if the performance is one of existing work in copyright. The reason attributed to this relatively unnoticed status of neighbouring rights of performers is that in the first instance, an author's creative effort takes concrete shape in the material form either as cinematograph film, audio record or a cassette. Until the event of film or record production, what the performers contribute to such work is only fleeting, disembodied and not in a tangible form. It lacks recognition under classical copyright theory. The film production of such a performance may evidence the performer's work. But even so, the film per se attracts copyright in tangible form as a film because the legal protection of a film is in the realm of copyright. ${ }^{66}$ Whereas the copyright owner can easily point to his work in its fixed form, the neighbouring rights owner has the difficulty of non-fixed evidence ${ }^{67}$ However, as stated above, with the emergence of special instruments on protection of performer's right, the protection of an unfixed work of a performer would no longer be an issue as protection is granted to an unfixed work of a performer. ${ }^{68}$ Thus, the absence of fixation no longer constitutes a problem; rather it is lack of implementation and recognition of these rights under the copyright laws that poses a problem; to the enforcement of performer's right.

Neighbouring rights also face the problem of enforcement, because performers cannot readily show their work in permanent form. Also because many persons can have a neighbouring right in a particular work of copyright, there is a conflict of claims which makes for difficulty in individual enforcement of the rights in a court. Hence it is submitted that a viable collective management society be put in place to enable the enforcement of these common rights. ${ }^{69}$ Collective management of performer's right is a system in which "owners of rights authorise collective management to monitor the use of their works, negotiate with prospective users, give licences against appropriate remunerations on the basis of a tariff system and under appropriate conditions, collect such remuneration and

\footnotetext{
${ }^{66}$ P. Ocheme, The LaW ANd Practice of Copyright in Nigeria 59 (Zaria: Ahmadu Bello University Press Ltd 2000).

${ }^{67} \mathrm{Ibid}$, at 59 .

${ }^{68}$ The Beijing Convention grants both economic and moral right to performers' fixed and unfixed work.

${ }^{69}$ O. O. Rotimi, Operation and Regulation of Copyright Collective Administration in Nigeria: Important Lessons for Africa (A paper presented in University of South Africa, May 2012).
} 
distribute it among the owner of rights" ${ }^{70}$. This system enables rights owners including Nigerian performers such as D’banj, Tu Face Idibia, J. Martins and a host of others in the Nollywood industry to concentrate on creativity whilst leaving the management of their rights to those who are best suited for doing so, in addition also giving an assurance that reward for creativity will accrue to the rights owners through payment of royalties as and when due.

Furthermore, there is the issue of employment as performers most times are employees although most authors are self-employed or at times commissioned. ${ }^{71}$ On many occasions, performers are in the employment of the copyright owners. ${ }^{72}$ If, for example, Chinua Achebe, the author of Things Fall Apart, hires cast and crew to do a life performance of the novel, he will simply have the entire cast and crew in his play. He will pay them off for their performance and proceed to complete the production as a personal work. It is pertinent to say here that unlike the case of copyright, the first owner of performers' right is the performer irrespective of whether he or she is an employee or whether he or she has been commissioned to make the performance. ${ }^{73}$

However, on other occasions, the live performer may be contracted by someone, who is not the author of work being performed. In this situation, the performer will not look like an employee, at least, not the employee of the author. Still, they would have been brought into the play of someone else. ${ }^{74}$ The purpose of such contract is to obtain the maximum benefit for each party from the allocation of rights. In order to achieve that goal, suitable incentives have to be offered to each, subject to the transaction costs of writing the contract and enforcing it. With a royalty contract, the performer shares the risk with the publisher (record label) and therefore stands to gain or lose from the works' success on the market, including any revival in its sales stimulated by the same performer's later work, thus giving the performer the incentive to produce consistently high quality works. However, there is a turn to it, in that the record label can exploit that by tying in the performer with an option to contract on future work yet to be done by the performer. For the employed performer, once he has been paid

\footnotetext{
${ }^{70}$ M. Fiscor, Collective Management of Copyright and Related Rights 17 (Geneva WIPO Publication No. 855 (E), 2002).

${ }^{71}$ JenNifer DAVIS, INTELLeCtuAl Property Law 111 ( $2^{\text {nd }}$ ed. London: Williams Clowes Ltd. 2003).

${ }^{72}$ Ocheme, Op. Cit., at 60.

${ }^{73}$ Manatu Ohanga, Performers' Rights: A Discussion Paper, by the Ministry of Economic Development, New Zealand, 17.

${ }^{74}$ Ibid.
} 
his wages, that extinguishes his right, save for his moral rights ${ }^{75}$ his remuneration will depend upon the terms of his contract with the copyright owner of the existing work performed, or whoever hires him for the live performance. In the music industry, most composers, lyricists and performers strive to be signed on by a record company. Those who are "fortunate" enough to do so will inevitably sign an exclusive recording contract, sacrificing much of their autonomy in the hope of success and prosperity. The copyright owner will grant the record company an exclusive license to exploit the works that he or she produces during the term of their agreement and the performer will grant the record company, the exclusive right to make recordings of their performances with a view of commercial exploitation and remuneration to the performer. Moreover, the right of remuneration which is not provided in the copyright Act does not enable performers to control the uses that are made of their performances. Rather, it recognises that performers should be entitled to benefit from the economic use that is made of those performances. Hence, it is fair to assert that if a performer adds value, she should be entitled to share in the revenue from the performance of the work. Performers' time has an alternative cost and unless they are rewarded accordingly, there is little (or less) incentive for performers to spend their time making recordings or other such work. Even if the performer were already on salary, economic efficiency requires that their pay reflect the revenues received by the organization employing them.

Again, the fact that performer's right accrues to each performer in a performance raises the issue of number to the effect that there may be a situation where a copyright work would be performed severally and the number of performers involved in the performance could be many and different from the copyright owner. Often, there are many performers involved in a performance, some who are featured performers but many who are not. It is often argued that the stars, the featured artists, always could reap their rewards via market mechanisms, such as the contractual arrangement with the theatrical producer or sound recording maker (the record label). A box office share or royalty contract ensures that the singer gets her portion of the success or otherwise of the music being performed. In the case of the non-featured performers, the view always expressed in the USA (which has not signed the Rome Convention) is that there is no justification for them to have an incentive contract because they do not add

\footnotetext{
${ }^{75}$ Ibid.

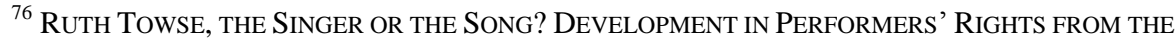
Perspective of a Cultural ECONOMist 10.
} 
any value to the protected work (the song). One should therefore ask why they deserve IP (in addition to the pay they get for the work), the standard US view. ${ }^{77}$ Apart from the misunderstanding about the real world payment arrangements for a lot of recording work by session performers, it could be asked how can a choral work acquire value without a chorus or an orchestral work without orchestral players or either without the conductor? ${ }^{78}$ In neighbouring rights, beginning from the first person who participated in the making of the performance to the last person, all have appropriate rights and a share of profits even if the proceeds are low. The issue of number also affects rights in the expressions of folklore. Folklores are not creations of any single person. ${ }^{79}$ They are group-oriented and tradition-based creation of groups or individuals reflecting the expectations of the community as an adequate expression of its cultural and social identity. Its standards and values are transmitted orally, by imitation or by other means just like folklore, folklore poetry and folk art in particular, drawings, paintings, carvings, sculptures, pottery, terracotta, ${ }^{80}$ mosaic, ${ }^{81}$ woodwork, metal work, indigenous textiles, etc. The Copyright Act does not vest the intellectual property in folklore in anyone; the property is the community's. What the law protects for an individual is the "expression" of folklore. It is now possible for more than one person to make different expressions of the same folklore. All these result in multiplicity of work on the same subject and possibly irreconcilable claims of rights.

The protection provided for performers is tied to the requirement of consent. Once a performer has consented to a particular form of exploitation of a performance, he or she loses control over that performance for that form of exploitation. Consent to the exploitation of a performance cannot be withdrawn once that exploitation takes place. Consent given to one person to exploit a performance means that another may exploit the performance, provided that the second person keeps within the bounds of the consent given to the first person. Thus, if a performer consents to person $\mathrm{X}$ recording his or her performance and broadcasting that recording, the performer cannot complain, under performers' rights, if person $\mathrm{Y}$ later

\footnotetext{
${ }^{77} \mathrm{Ibid}$, at 9.

${ }^{78}$ This is to emphasize the value each and every performer who participated in a performance add to the work and thus acquires a right in the said work.

${ }^{79}$ S. M. STEWART, InTERnATIONAL COPYRIGHT AND NEIGHBouring Rights 112 (London: Butterworths 1985).

${ }^{80} \mathrm{~A}$ hard semi fired waterproof ceramic clay used in pottery, building construction and as a material for sculpture.

${ }^{81}$ A picture or pattern produced by arranging together small pieces of hard material, such as stone, tile, or glass.
} 
broadcasts the performance (although person $\mathrm{X}$ might be able to prevent person $\mathrm{Y}$ from doing so). The nature of the consent that is given by a performer is therefore a critical issue. It is usually a matter for negotiation in which the performer may not be in a strong bargaining position. ${ }^{82}$ However, there is a conventional wisdom today that performer's rights are being exploited without their consent. For instance, the broadcasting organisations assume they have a "license" to broadcast without consent as a favour to the performers who require publicity. Whereas in a copyright work the only consent required is that of the author of the work, in neighbouring rights the consent of each and every individual who took part in the performance must be sought and obtained. ${ }^{83}$ However, the challenges of distance, means of communication, ability to actually locate the performer and response time by the performer to the intended user are all issues for consideration. Thus, it is submitted that the above challenge can be resolved by putting in place a system of collective administration of copyright and neighbouring rights.

\section{ENFORCEMENT AND PROTECTION OF PERFORMER'S RightS IN NIGERIA:} THE POSITION OF THE COURT AND THE NIGERIAN COPYRIGHT COMMISSION (NCC) IN THE ENFORCEMENT OF PERFORMER's RIGHTS

Performers in Nigeria have been valued for centuries in different tribes and communities. Folk plays, folk dances, folk songs, folk poetry, folk riddles and instrumental folk music were performed in communities in the pre-colonial era and they are still being performed in most communities in rural as well as urban areas. ${ }^{84}$

The landscape for performing artists in Nigeria has changed due to improvements in technology. It is possible to record live performance or live broadcast without the consent of the performer in Nigeria. Location is no longer a barrier. Performances in Nigeria are recorded and taken to other parts of the world and disseminated to the public. The internet makes it much easier to send information to places known and unknown to the sender or even the performer. Thus, technological developments are perceived as the most dangerous threat to a performer's control over his performance. ${ }^{85}$ As a result of the social changes that occurred from the invention and use of

\footnotetext{
${ }^{82}$ Manatu Ohanga, Op. Cit., at 13.

${ }^{83}$ John O. Asien, Nigerian Copyright Law \& Practice 337 ( $2^{\text {nd }}$ ed. Abuja: Books and Gavel Ltd., 2012).

${ }^{84}$ Ayoyemi Lawal, Performers' Rights under Nigerian Copyright Law: An Appraisal of Rome Convention, 2(4) Nigerian LaW InTellectual Property Watch Copyright LaW 1-31 (2014).

${ }^{85}$ Michael Gruenberger, A Duty to Protect the Rights of Performers? Constitutional Foundations of an Intellectual Property Right, 24 CARDOZOS ART AND ENTERTAINMENT 617 (2006).
} 
recording devices, strategic action is being taken to ensure the enforcement of copyright and neighbouring rights in Nigeria. ${ }^{86}$ Despite the enactment of the Copyright Act and the provisions on performer's right, there are lacunae in the law. First, the Act made no provision for the moral rights of a performer. Secondly, there is no clear provision on eligibility. Are performer's rights subject to the eligibility requirement in Sections II-V? What is the legal status of a performance by foreigners or performance made on foreign soil? Who owns a performance that is made by or under the control of the Federal Government? Do the rules of first ownership and assignment as in the case of copyright apply to performances? Thirdly, the Act does not expressly provide for exceptions in respect of performers' rights, as the second schedule deals only with exception for copyright control. ${ }^{87}$ These are areas where courts would have to be more creative in providing solutions to these questions; unfortunately, there are no case laws on issues of performer's rights in Nigeria, unlike their counterparts in the United Kingdom, where the courts have recognised the rights of performers to enforce their actions. ${ }^{88}$

In the context of the Nigerian film industry, the application of some of the protective provisions of the copyright law, presents a serious problem. It is sometimes difficult to establish with reasonable certainty who is responsible for the making of the film. Usually the relationship, between those responsible for the artistic content of the film on the one hand and those who provide necessary finance on the other, is not well defined. This, as experience has shown, is a potential source of conflict. The solution here lies in creating a regime of express contracts as contemplated by the Act. ${ }^{89}$ Thus, a producer of a film is enjoined by the Act to conclude, prior to the making of the film, contracts in writing with all those whose works are used in the making of the film. The rationale of this provision is that the law recognises the independent status and creative quality of the different components that make up a film. While the final product becomes the intellectual property of the producer, the law nevertheless seeks to protect the interest of other authors whose works are included in the film. ${ }^{90}$ The

\footnotetext{
${ }^{86}$ Ratification of the International Conventions on Performers Right by Nigeria and the Statutory Protection in the Nigerian Copyright Act (2010).

${ }^{87}$ John O. Asien, Nigerian COPYRIGHT LAW \& Practice 336 ( $2^{\text {nd }}$ ed., Abuja: Books and Gavel Ltd. 2012).

${ }^{88}$ In the case of Apple Corps Ltd and Others v. Lingasong Ltd. [1977] F. S. R. 345, at 350, where the courts have acknowledged that performers might have a cause of action based on damage to any goodwill that they may possess in their performances, e.g. through the circulation of bootleg records of inferior quality. This principle was also applied in Shelley $v$ Cunane [1983] F. S. R. 390.

${ }^{89}$ Section 9(4) NCA.

${ }^{90}$ The performers would come in here.
} 
experience in the Nigerian entertainment industry however shows that many performers still do not have the benefit of sound contracts. Although the law has provided a basis for their engagement, the absence of professional managers and advisors has often exposed performers to exploitation through unconscionable contractual arrangements entered into with producers or, in some cases, total absence of contract. These factors have affected the fortunes of performing artistes and generally the orderly growth of the entertainment industry. To this end, if there is a presence of a strong guild (Performers' Association) which could provide a platform for collective bargaining and setting of minimum engagement terms, this will prevent a scenario where the fortunes of a performer are left to be determined solely by producers who are naturally the stronger parties in the bargain. ${ }^{91}$

One of the greatest hindrances to adequate return on investments both to the rights owners and producers in the film industry although the export potential is piracy. It has been discovered that almost all exports of Nollywood films are pirated copies. The World Bank estimates that for every legitimate copy sold, nine others are pirated.$^{92}$ In spite of the elaborate provisions of the law, practical reality shows that it is still difficult for authors, performers and other rights owners to gain the full benefit of the copyright system. There is no doubt that piracy, counterfeiting and other intellectual property abuses remain one of the negative challenges to the development of the entertainment industry particularly the exploding film industry. Piracy, which may be defined as the unauthorised commercial exploitation of copyright works, thrives in an environment devoid of control and inadequate regulation and enforcement. ${ }^{93}$ Piracy has become not just an act of infringement of the rights guaranteed under copyright law but has grown into an industry, a systematically organised industry that erodes the viability of an emerging copyright system as well as the gains of copyright protection. Studies have shown that the problem of piracy is indeed global and ravaging the various categories of entertainment products. ${ }^{94}$ With the trend of new media information and telecommunication technology, it is becoming more difficult for authors to maintain firm control over their works in line with the classical rights guaranteed by the copyright law. For instance, films, when digitalised and produced in the DVD format, are more prone to being copied and susceptible to easy communication and

\footnotetext{
${ }^{91}$ Abayomi O. Oyelola, mni, Nollywood and Copyright Administration in Nigeria: Implications for National Development, published on 31 July 2015, www.sonta.nico.gov.ng (Retrieved on 10 October, 2016).

${ }^{92}$ Ibid.

${ }^{93} \mathrm{Ibid}$.

${ }^{94}$ Ibid.
} 
distribution. Millions of films are being downloaded in breach of copyright each day. ${ }^{95}$

The Nigeria Copyright Commission on the other hand has not done much towards the protection of neighbouring rights. The situation one finds on ground in Nigeria is that the commission administers copyright in Nigeria as if it pertains only to copyright and not to neighbouring rights. The operation of the commission is not widespread across the country. It somewhat focuses in and around Lagos and Iweka road in Onitsha. Neighbouring rights seem almost removed from the focus of the commission. ${ }^{96}$ Enquiries at the Nigeria Copyright Commission show that there have been complaints of unauthorised fixation of performances communicated to the public. However, such complaints went no further than being mere complaints. Performers perceive bootlegging as a problem for the recording company or the individual who records the performance. ${ }^{97}$

\section{TaCKLing the Challenges Facing Performer’s Right}

Collective Management System is one of the means by which the challenges encountered by performers can be addressed. Collective management is a system in which "owners of rights authorise collective management organisations to monitor the use of their works, negotiate with prospective users, give licenses against appropriate remunerations on the basis of a tariff system and under appropriate conditions, collect such remuneration and distribute it among the owners of rights." 98 The rationale for this system of management arises from the impracticability of managing these activities individually, namely the inability of the individual rights owner to personally monitor and enforce all of his rights in every situation where his works are used. ${ }^{99}$ The members of a collective management organisation can be all the holders of copyright or of rights related to copyright, such as: authors, composers, publishers, writers, photographers, musicians, performers, etc. In Nigeria collective management of rights can be seen in the area of copyright under the Copyright Act. ${ }^{100}$ No provision is made for such in the area of neighbouring rights. However, there are

\footnotetext{
${ }^{95} \mathrm{Ibid}$.

${ }^{96}$ S. N. Anya, Mimeograph Lecture Note, "Neighbouring Rights", University of Nigeria, Enugu Campus, 10 (2014).

${ }^{97}$ Survey of Copyright Piracy in Nigeria, NCC/FORD FoundATION 1 (June 2008).

${ }^{98}$ M. IsCOR, COLLECTIVE MANAGEMENT OF COPYRIGHT AND RELATED Rights 17 (Geneva: WIPO Publication No. 855 (E), 2002).

${ }^{99}$ A. Adewopo, Nigerian Copyright Systems Principles And Perspectives 81 (Odade Publishers 2012).

${ }^{100}$ Section 39 Nigerian Copyright Act.
} 
recognised associations in that area: for example, the Performing Musicians Association of Nigeria (PMAN) and Nigerian Union of Musicians (NUM). These associations are like a guild and thus their focus is on their members' interests and not on the enforcement of rights. Hence, it can be said that collective management in the field of copyright and neighbouring rights in Nigeria is not effective, unlike their counterparts in the European countries where collective organisations are key to the protection and enforcement of neighbouring rights in addition to judicial enforcement. ${ }^{101}$ The benefit of the system is also double-edged in the sense that it safeguards the interests of authors and performers, and also provides an accessible and easy-to-use platform to users desirous of engaging in legitimate exploitation of a work. ${ }^{102}$ Thus collective management serves the purpose of bridging the gap between owners and users by simultaneously addressing the needs and concerns of both parties.

The issuance of the Copyright (Security Devices) Regulations 1999 has introduced anti-piracy measures. The regulations were made pursuant to the powers vested in the Commission by the Act. ${ }^{103}$ The regulations prescribe the compulsory use of hologram, an anti-piracy security stamp on all sound recordings and cinematograph films intended or offered for sale, rental, hiring, lending, or otherwise distributed to the public for commercial purposes in Nigeria. The essence of this prescription is to make it possible to distinguish genuine copyright works from counterfeit copies. Any tape not carrying the hologram is deemed a pirated copy and may be confiscated during anti-piracy operations of the Commission. It is an offence under the law for any person to distribute or sell any work envisaged under the regulation without affixing the hologram; or to produce or import into the country any prescribed anti-piracy device without the Commission's authorisation under a single platform.

Furthermore, the Video Rental Scheme has the potential of enhancing the revenue prospects of movies by ensuring that all rental activities in respect of movies are paid for in advance. Given the prevalence of rental activities, this option is therefore a significant avenue of harnessing the benefit of the copyright system for film producers. As a result, the Nigerian Copyright Commission issued the Copyright (Video Rental) Regulations 1999 as a response to complaints from rights owners in the movie industry

\footnotetext{
${ }^{101}$ This is so in the United States where there are three highly active collective organisations as well as judicial enforcement where the courts have employed the common law doctrines in deciding cases on infringement of performer's right.

${ }^{102}$ Fiscor, Op. Cit., at 16.

${ }^{103}$ Section 21 NCA.
} 
against the widespread illegal rental of their works.

Finally, implementation of the international instrument for the protection of performer's rights as well as the ratification of the Beijing Treaty for protection of audiovisual performances would ensure that performer's rights are duly acknowledged and protected.

\section{CONCLUSION}

It has been rightly stated that copyright and performers' rights are essential to human creativity by giving creators incentives in the form of recognition and fair economic rewards. As a result of this recognition and fair economic reward, the enjoyment of culture, knowledge and entertainment is enhanced. Performers have rights almost equivalent to those of authors and copyright owners conferred on them by the Act as well as international instrument for the protection of performer's rights.

The problem for performers is that they do not have a "level playing field" as we saw above that while contracted performers typically negotiate individual royalty contracts for sales and therefore receive their royalty payments direct from the publisher (or record label), commissioned performers until now have been paid a flat fee for making the sound recording. Thus, the method of ensuring that performers gain recognition and fair economic rewards for their talent is by making performers aware of the legal protection of performer's rights through collective administration of copyright and related rights, both by the NCC and collecting societies. Also, law reform and review is imperative to take account of the peculiar nature of performer's rights by implementing the necessary international instrument that has made adequate provision for the protection of performer's rights and to expand the scope of protection of performer's rights by addressing the issues of eligibility, legal status of performance made in foreign land, ownership and assignment.

A good guide would be the Rome Convention after which the provisions on performer's rights are modeled and the ratification of the Beijing Treaty. It is appropriate also that there should be an amendment of the provision of sections 31(4) and 32 of the Act, which precludes the owner of rights in the expression of folklore from exercising and asserting the rights without the consent of the Commission. The owner of any specie of copyright should have the right to enforce it directly. This will give equal status to the rights. Finally, there should be an expanded use of the judicial process as it is necessary that the Nigerian courts should get involved in the enhancement and enforcement of performer's rights as practiced in other countries like India and the United States of America. 